УДК 340.0:340.1

DOI https:// doi.org/10.32837/yuv.v0i1.1529

\author{
Н. Гураленко, \\ доктор юридичних наук, доцент, \\ доцент кафедри людських прав \\ юридичного факультету \\ Чернівецького національного університету імені Юрія Федьковича

\section{T. Коханюк,} \\ кандидат юридичних наук, \\ завідувач відділення організації освітньо-наукової підготовки \\ Львівського державного університету внутрішніх справ
}

\title{
СТАДІї ЮРИДИЧНОЇ ВІДПОВІДАЛЬНОСТІ: АНАЛІЗ СТРУКТУРНИХ ЕЛЕМЕНТІВ
}

Без юридичної відповідальності право стає безсилим, не виправдовує соціальних очікувань. Чимало процесів і напрямів правового розвитку пов'язані з відчуттям захищеності кожного, гарантованості прав і законних інтересів, протистоянням сваволі в процесі впорядкування суспільний відносин.

Сучасне право передбачає цивілізовані засоби юридичної відповідальності, відповідні демократичному розвиткові. 3 моменту вчинення правопорушення юридична відповідальність проходить певні стани - від виникнення до іï конкретизації залежно від установленого складу правопорушення й реалізації призначеного заходу юридичної відповідальності. Саме тому сьогодні одним із ключових напрямів наукового дослідження стає питання стадій і процедурних закономірностей функціонування юридичної відповідальності, що не лише дають змогу чітко визначити спеціальний статус правопорушника на різних етапах динаміки розвитку юридичної відповідальності, a й сприяють зміцненню законності, $€$ безсумнівним складником механізму впровадження правового порядку в усіх сферах суспільного життя.
Вагомий внесок у дослідження різноманітних проблем, які безпосередньо стосуються поняття, сутності, видів, принципів, завдань і функцій юридичної відповідальності, співвідношення іiі 3 такими правовими явищами, як правопорушення, санкція правової норми, покарання, юридичний обов'язок, зробили I. Аземша, В. Байрачний, К. Басін, Н. Батанова, Ю. Баулін, І. Безклубий, Є. Білозьоров, М. Богданова, С. Братусь, М. Вітрук, В. Грищук, М. Задніпровська, О. Іваненко, Л. Калєніченко, С. Кондратьєва, В. Кудрявцев, Д. Липинський, О. Максимюк, В. Малиновська, M. Матузов, А. Малько, В. Марчук, Н. Петрицин, Є. Подорожній, П. Рабінович, К. Сенякін, О. Тихомиров, Р. Хачатуров, М. Шиндяпіна, А. Шульга й ін.

Не применшуючи ролі та значення доробки згаданих науковців, варто відзначити, що питання стадійності правових процедур здійснення юридичної відповідальності набули дискусійного характеру вивчення у вітчизняній юридичній літературі. Саме останнє зумовлює актуальність вибору проблеми дослідження та визначає його мету. 


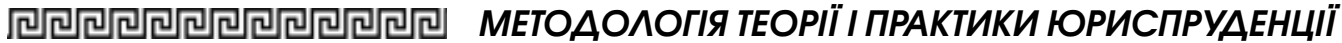

Відсутність у науковій літературі єдиної позиції стосовно пізнання істинного змісту юридичної відповідальності викликала численні дослідження, сфера яких поширюється від абстрактних до вузькопрагматичних точок зору, від абсолютизації однієї з форм юридичної відповідальності - ретроспективної (негативної) або перспективної (позитивної) - до позиції їх діалектичної єдності [1], що найбільше здатна відобразити багатогранність цього феномена.

Ретроспективна (негативна) юридична відповідальність - це встановлення й застосування державою різних заходів покарання за здійснення суб'єктом протиправного діяння, що порушує приписи правових норм; особливий вид юридичної відповідальності, вона є відповідною реакцією суспільства та держави на здійснене особою винне протиправне діяння у формі застосування до неї заходів державного примусу, серед яких особисті (позбавлення волі); майнові (штраф); організаційні (звільнення).

Разом із тим, з одного боку, юридична відповідальність пов'язана 3 державою, правовими нормами, правомірною та протиправною поведінкою суб'єктів права, але з іншого - юридичну відповідальність не потрібно сприймати лише як наслідок правопорушення, негативну реакцію держави на правопорушення, оскільки відповідальність у широкому сенсі та юридична відповідальність зокрема має й позитивний аспект.

Перспективна (позитивна) юридична відповідальність - це усвідомлення суб'єктом своїх дій і співвідношення цих дій зі змістом чинних правових норм. Позитивна юридична відповідальність $є$ засобом, завдяки якому юридична відповідальність реалізується в правомірній поведінці особи, стає підгрунтям для дотримання та виконання норм права, що певним чином має заохочуватися державою [2, с. 52].

У будь-якому суспільстві ретроспективний (негативний) i перспективний (позитивний) аспекти юридичної відпо- відальності тісно пов'язані між собою: чим вищий рівень відповідальності в активному сенсі (позитивна відповідальність), тим краще в суспільстві дотримуються соціальні норми й рідше застосовується відповідальність у ї̈ ретроспективному аспекті (негативна відповідальність) [3].

Якщо фактичною підставою ретроспективної (негативної) юридичної відповідальності $€$ правопорушення, яке характеризує сукупність ознак, що утворюють його склад, то юридичною підставою - норма права та відповідний правозастосовний акт, у якому компетентний орган установлює конкретний обсяг і форму примусових засобів до конкретного правопорушника.

Юридична відповідальність не проявляється й не діє автоматично в разі вчинення правопорушень. Юридична відповідальність - динамічне правове явище, пізнання якого відбувається в процесі активної владної пізнавально-оцінювальної діяльності компетентних державних органів і посадових осіб, яка одержала назву правоохоронної (позитивно-правозастосовної, юрисдикційної) діяльності й має свої особливості на конкретних стадіях прояву юридичної відповідальності.

Cтадіï юридичної відповідальностіце етапи (періоди) у динаміці буття юридичної відповідальності від виникнення внаслідок правопорушення до іï припинення в результаті реалізації правопорушником призначеного йому заходу юридичної відповідальності. Стадії юридичної відповідальності являють собою визначені етапи розвитку (реалізаціі) процесу юридичної відповідальності, що характеризуються особливими цілями, на досягнення яких спрямована діяльність юрисдикційних органів [4, с. 6]. У процесі свого розвитку юридична відповідальність проходить три стадіі: 1) виникнення юридичної відповідальності; 2) установлення й призначення заходу юридичної відповідальності; 3) реалізація заходу юридичної відповідальності.

Перша стадія юридичної відповідальності починається 3 моменту ї 


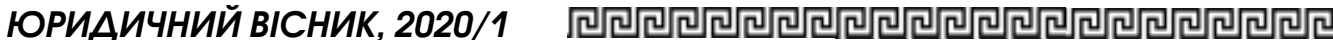

виникнення, тобто вчинення правопорушення, і триває до виявлення правопорушення компетентними органами держави й посадовими особами. Факт правопорушення $€$ не лише основою юридичної відповідальності, а й самим моментом виникнення правовідношення відповідальності.

Поштовхом до розвитку правовідношення відповідальності й, відповідно, реалізації наступних стадій відповідальності слугують активні дії сторін. У цьому випадку активність - пріоритет держави, хоча й не виключено, що правопорушник першим буде реалізовувати свій обов'язок понести покарання (наприклад, у разі явки з повинною).

Друга стадія юридичної відповідальності (стадія конкретизаціі) розпочинається 3 виявлення правопорушення компетентними органами держави й посадовими особами та завершується вступом у законну силу акта застосування права, у якому визнається факт правопорушення, здійсненого певною особою.

Під виявленням правопорушення варто розуміти фіксацію уповноваженими на те органами держави явних ознак правопорушення. Форма фіксації може бути різною: по-перше, безпосереднє виявлення ознак правопорушення уповноваженими на те органами держави; по-друге, повідомлення від самого правопорушника про вчинене ним протиправне діяння; по-третє, заяви від громадян, підприємств, установ, організацій; по-четверте, повідомлення в засобах масової інформації.

У разі достатньої наявності матеріалів виноситься рішення про порушення справи у зв'язку з учиненням правопорушення, а згодом і рішення про притягнення до юридичної відповідальності. Ця стадія включає «розпредмечування» юридичної відповідальності в процесі владної діяльності компетентних органів і посадових осіб із метою достовірного встановлення правопорушника й складу скоєного ним правопорушення, об'єктивне та справедливе визначення виду й заходу юридичної відповідальності. У зв'язку із цим змістом стадії конкретизації юридичної відповідальності слугує кваліфікація здійсненого правопорушення, тобто одержання та оцінювання фактів, що підтверджують або спростовують учинення правопорушення конкретною особою.

У найбільш загальному розумінні юридична кваліфікація розглядається як визначення певним суб'єктом правового змісту окремої фактичної ситуації. Таке розуміння дає змогу визнати їі відносно самостійним соціально-правовим явищем, яке має власний («внутрішній») зміст і водночас взаємодіє (може взаємодіяти) 3 іншими компонентами соціально-правової дійсності [5, с. 24]. Власний зміст юридичної кваліфікації розкривають такі іï характеристики: по-перше, юридична кваліфікація має два елементи - гносеологічний (пізнавальний, розумовий) та оціночний; по-друге, у структурному стосунку юридична кваліфікація правопорушення передбачає наявність об’єкта, суб'єкта та предмета кваліфікації.

Гносеологічний елемент юридичної кваліфікації являє собою мисленнєвий процес співставлення реального життєвого факту з ідеальною конструкцією цього факту, передбаченою нормою права. Кінцевий етап такого процесу завжди формалізується (об'єктивується - проголошується, викладається в письмовій формі тощо).

Ціннісний елемент юридичної кваліфікації виражається в тому, що юридичні норми, на основі яких відбувається кваліфікація, містять у собі вже визначену оцінку фактів з погляду відображеної законодавцем системи соціальних цінностей. Оціночно-пізнавальний складник - це різновид розумової діяльності, що відбувається в межах людської свідомості; виходячи із цього, первинний предмет юридичної кваліфікації - фактичні обставини 3 відповідним об’єктивним («реальним») змістом - трансформується у відображену у свідомості суб'єкта («ідеальну») інформаційно-оціночну модель цих 


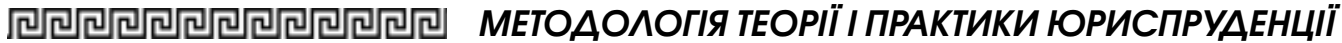

обставин; саме така модель і є безпосереднім предметом юридичної кваліфікації; при цьому як первинні стандарти (орієнтири) оцінювання виступають певні «фрагменти правової матеріі» (нормативні приписи, правові принципи, нормативні юридичні конструкції тощо); однак, будучи «перенесені» у сферу свідомості (правосвідомості), вони також набувають форми певних «ідеальних» моделей, і саме такі похідні моделі є безпосередніми орієнтирами визначення правового змісту інформаційно-оціночної моделі фактичних обставин. Отже, у найбільш загальному вигляді специфічний правовий зміст юридичної кваліфікації утворюють: а) окремі етапи процесу розумової (оціночно-пізнавальної) діяльності людини (суб'єкта кваліфікації); б) формалізацію їі результату.

Окремими етапами процесу оціночно-пізнавальної діяльності суб'єкта кваліфікації $€$ : а) зіставлення інформаційно-оціночної моделі фактичних обставин із моделями відповідних правових орієнтирів; б) вибір тих правових орієнтирів, які, на думку суб'єкта, найбільш повно, точно й конкретно визначають правовий зміст зазначеної моделі; в) формулювання конкретного висновку щодо правового змісту окремої фактичної ситуації.

Формалізація зробленого на завершальному етапі висновку щодо правового змісту окремої фактичної ситуації передбачає його вклад у певній формі (кількох формах); при цьому дотримання такої форми (форм) у більшості випадків пов'язане 3 виконанням відповідних техніко-юридичних правил. Взаємодія окремих складників юридичної кваліфікації, передусім ї результату, 3 іншими компонентами соціально-правової дійсності надає їй певної «зовнішньої» значущості. У цьому плані залежно від специфіки таких компонентів і характеру взаємодії можна вести мову, зокрема, про інформаційне, теоретичне, етичне i власне правове значення юридичної кваліфікації.
Правового значення юридична кваліфікація набуває тоді, коли іiі складники пов'язані 3 реалізацією певних правовідносин. У цьому разі вона стає правовою (юридично значущою) дією, що включається у відповідну форму реалізації права.

Оскільки конкретизація юридичної відповідальності та кваліфікація правопорушення $є$ процесами взаємопов'язаними й взаємозумовленими, то, безумовно, базисом конкретизації відповідальності є норма права, яка використовується під час кваліфікації правопорушення, до того ж та іï частина, яка передбачає захід юридичної відповідальності, тобто правоохоронну санкцію.

Остаточна конкретизація юридичної відповідальності виражається під час винесення рішення по справі у зв'язку з учиненням правопорушення та набрання ним законної сили. У процесі пізнання складу правопорушення складаються відповідні процесуальні документи: у провадженні справи про адміністративні правопорушення складаються протоколи про адміністративне правопорушення, протоколи про адміністративне затримання, протоколи про вилучення речей, постанова по справі про адміністративне правопорушення; процес пізнання цивільно-правового правопорушення завершується прийняттям рішення суду; дисциплінарного проступку - наказом власника підприємства, установи або організації або уповноваженого ним органу; злочину - вироком суду. Відповідаючи передбаченим законом вимогам, усі вищезгадані процесуальні документи повинні в резолютивній частині передбачати конкретний захід юридичної відповідальності. Отже, процесуальний акт, під час прийняття якого завершується процес кваліфікації правопорушення, стає водночас й актом остаточної конкретизації юридичної відповідальності.

Загальна оцінка діяння як правопорушення свідчить про завершення конкретизації юридичної відповідально- 


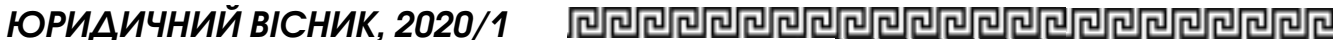

сті - визначення виду та заходу відповідальності, отже, установлюється той обсяг прав, свобод та обов'язків правопорушника, який характеризує його правовий статус як спеціальний. Цей факт зумовлює подальший розвиток юридичної відповідальності й настання третьої стадії - реалізації юридичної відповідальності, тобто реального зазнання правопорушником негативних наслідків, пов'язаних зі зміною його правового статусу.

третя стадія юридичної відповідальності - реалізація юридичної відповідальності, розпочинається з моменту вступу в законну силу правозастосовного акта, яким установлено вид і захід юридичної відповідальності й завершується, за загальним правилом, тоді, коли призначене покарання реалізоване.

На стадії реалізації юридична відповідальність матеріалізується. На цій стадії юридична відповідальність виступає як захід державного примусу, який полягає в негативних наслідках для правопорушника, що настають у вигляді обмежень майнового чи особистісного характеру. Зі змістового боку стадія реалізації юридичної відповідальності характеризується передусім наявністю спеціального правового статусу правопорушника.

Отже, аналізуючи вищесказане, можемо констатувати, що юридична відповідальність належить до процесуальних сфер життєдіяльності, де винятково важливо не тільки те, що робиться, а й те, який порядок здійснюваних дій. Формалізація, фіксованість, хронологічність, циклічність, сувора послідовність операцій, опосередковувальний характер системних зв'язків i відношень, що виникають між різними стадіями оформлення результатів у відповідних процесуальних документах, наочно розкривають конструктивність та архітектоніку юридичної відповідальності.

У статті встановлено, що юридична відповідальність - не лише реакиія держави на вчинене правопо- рушення, а й свідоме, відповідальне ставлення індивідів до своїх вчинків. Акцентовано увагу на формалізації, послідовності операцій, хронологічності й изиклічності юридичної відповідальності як на своєрідних спеціально створених етапах, що порядок протиставляють хаосу, свободу свавіллю.

Визначено стадії юридичної відповідальності як етапи (періоди) у динаміці розвитку юридичної відповідальності від виникнення внаслідок учинення правопорушення до ї припинення в результаті реалізаизї правопорушником призначеного йому заходу юридичної відповідальності. Констатовано, щзо в процесі свого розвитку юридична відповідальність проходить три стадіï: виникнення юридичної відповідальності; установлення й призначення заходу юридичної відповідальності; реалізація заходу юридичної відповідальності. Досліджено стадію виникнення юридичної відповідальності, яка починається з моменту вчинення правопорушення $i$ триває до виявлення правопорушення компетентними органами держави й посадовими особами. Досліджено стадію конкретизації юридичної відповідальності, яка розпочинається з виявлення правопорушення компетентними органами держави й посадовими особами та завершується вступом у законну силу акта застосування права, у якому визнається факт правопорушення, здійсненого певною особою. Зауважено, що змістом стадії конкретизаціі юридичної відповідальності слугує кваліфікація здійсненого правопорушення, тобто одержання й оиінювання фактів, шо підтверджують або спростовують учинення правопорушення конкретною особою. Досліджено стадію реалізації юридичної відповідальності, яка розпочинається з моменту вступу в законну силу правозастосовного акта, яким установлено вид $i$ захід 


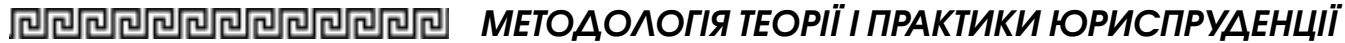

юридичної відповідальності й завершується, тоді, коли призначене покарання реалізоване.

Ключові слова: юридична відповідальність, стадії юридичної відповідальності, ретроспективна (негативна) юридична відповідальність, перспективна (позитивна) юридична відповідальність, юридична кваліфікація.

Huralenko N., Kohaniuk T. Legal liability stages analysis of structural elements

The article establishes that legal responsibility is not only the reaction of the state to the offense, but also the conscious, responsible attitude of individuals to their actions. Emphasis is placed on the formalization, sequence of operations, chronology and cyclicality of legal responsibility as a kind of specially created stages that oppose order - chaos, freedom - arbitrariness. The stages of legal responsibility are defined as stages (periods) in the dynamics of development of legal responsibility from occurrence as a result of the commission of the offense to its termination as a result of realization by the offender of the measure of legal responsibility assigned to him.

In the course of its development, legal responsibility goes through three stages: legal liability; establishing and assigning a measure of legal responsibility; implementation of a measure of legal responsibility. The stage of emergence of legal liability, which starts from the moment of committing the offense and continues until the detection of the offense by the competent state authorities and officials, has been investigated. The stage of specification of legal responsibility is investigated, which begins with the detection of an offense by the competent authorities of the state and officials and ends with the entry into force of an act of application of law in which the fact of an offense committed by a certain person is recognized; the content of this stage is the qualification of the offense, that is, the receipt and evaluation of facts that confirm or deny the commission of the offense by a specific person. The stage of realization of legal liability, which begins from the moment of entry into force of a law enforcement act, which determines the type and degree of legal responsibility and ends when the punishment is implemented, is investigated.

Key words: legal liability, stages of legal liability, retrospective (negative) legal liability, prospective (positive) legal liability, legal qualification.

\section{Література}

1. Аземша І.Б. Юридична відповідальність: сучасні погляди, дискусії та концепціі. Часопис Київського університету права. 2010. № 2. С. 54-57.

2. Білозьоров Є. Юридична відповідальність як передумова правомірної поведінки особи: теоретичні аспекти. Право України. 2006. № 4. C. 50-54.

3. Голубовський B.Є. Діалектика правомірної поведінки та юридичної відповідальності. Національний вісник Національної академії внутрішніх справ. 2011. № 6. С. 10-18.

4. Калєніченко Л.I. Юридична відповідальність як динамінне правове явище. Форум права. 2017. № 3. С. 67-71.

5. Кудрявцев М.Г. Общая теория квалификации преступлений. Москва : Юристь, 1999. C. 59.

6. Шиндяпина М.Д. Стадии юридической ответственности : учебное пособие. Москва: Книжный мир, 1998. 168 с. 